\title{
EFFECT OF STEAM EXPLOSION ON ENZYMATIC HYDROLYSIS OF VARIOUS PARTS OF POPLAR TREE
}

\author{
Andrej Pažitný, Albert Russ, Štefan Boháček, Monika Stankovská, Vladimír Ihnát \\ Pulp and Paper Research Institute \\ Slovak Republic \\ ŠTEFAN ŠUtÝ \\ Slovak University of Technology \\ Slovak Republic \\ (Received December 20i9)
}

\begin{abstract}
The effect of steam explosion on enzymatic hydrolysis of various parts of poplar tree (heartwood, sapwood and 1-year coppice) was investigated. These parts were milled, the obtained sawdust was chemically analysed and then steam explosion of $0.7 \mathrm{~mm}$ poplar particles at temperature of $205^{\circ} \mathrm{C}$ was performed. Concentration of monomers obtained after enzymatic hydrolysis was considered as the main indicator for cellulose accessibility. Analysis of high performance liquid chromatography showed that non-treated poplar sawdust does not enable sufficient cellulose accessibility, while excessively high temperature and rapid pressure release resulted in substantial breakdown of polysaccharides and lignin and formation of inhibitors. The concentration of monomers increased gradually in the order of coppice, sapwood and heartwood. Steam exploded heartwood gave the maximum monosaccharides concentration of $90.0 \mathrm{~g} \cdot \mathrm{L}^{-1}$ after 72 hours of enzymatic hydrolysis. However, glucose concentration culminated after 48 hours of this hydrolysis. This corresponds to the best holocellulose accessibility for enzymes. The maximum concentration of inhibitors $\left(9.3 \mathrm{~g} \cdot \mathrm{L}^{-1}\right)$ was determined for poplar coppice after 24 hours of enzymatic hydrolysis.
\end{abstract}

KEYWORDS: Coppice, heartwood, Populus alba, sapwood, second generation bioethanol, steam explosion, pretreatment. 


\section{INTRODUCTION}

The white poplar (Populus alba L.), also known as silver poplar or silverleaf poplar (Webb et al. 1988), is a species most closely related to the aspens. Poplars are traditionally grown on formerly agricultural land but forest land holds great potential for poplar production due to available large area for possible growth of such woody plants (Böhlenius et al. 2020). In many parts of the world, fast-growing trees of the genus Populus are the most appropriate, and are often used in plantation forestry, eventually, poplar plantations are considered intensively for their conversion into bioenergy, especially bioethanol (DeBell and Harrington 1997, Tullus et al. 2007, Christersson 2008, Mao et al. 2010, Tullus et al. 2012, Kačík et al. 2012, Dimitriou and MolaYudego 2017, Böhlenius et al. 2020). Although some fast-growing plants such as several species of Miscanthus have been experimentally grown in Slovak Republic (Prčík and Kotrla 2016), soft fast-growing trees (such as poplars) are a good alternative for second generation bioethanol production due to their better land availability and relatively high holocellulose content (Krutul et al. 2019). The fast-growing trees (also include willows, alders and acacias or wooden bushes) are usually cut younger and the period between their planting and harvesting is significantly shorter compared to the standard trees which are woody perennial plants with single, well-defined stem and grow among forest vegetation. The period between fast-growing trees planting and harvesting ranges between 2 years and 5 years and planting is usually renewed between twentieth and thirtieth year of their age. It is also known that the fast-growing woody plants are able to produce a larger volume of biomass in the same area every year when compared to standard perennial trees. Some fast-growing tree species could also counteract growth losses owing slash and stump harvest (Jong et al. 2017). The crucial parameters in the selection of fast-growing trees include their availability, suitability for the given soil type, climatic conditions and potential annual yields per hectare. In our geographical region, the growth of dry matter can reach 4.67 tonnes $\cdot \mathrm{ha}^{-1}$ year ${ }^{-1}$ for poplars and 5.09 tonnes ha $^{-1} \cdot$ year $^{-1}$ for willows, respectively (Stolarski et al. 2013).

The cellulose and lignin content in wood increases gradually in parallel with age, while content of hemicelluloses (pentosans) decreases (Prosiński 1984). Thus, the lower lignin content in fast-growing trees can be advantageous because lignin is one of the inhibitors of $2 \mathrm{G}$ bioethanol production processes. With regard to these processes, lignin is not a desirable component in plant cell, as it is particularly difficult to biodegrade. Its recalcitrant nature makes this threedimensional polymer molecule a physical obstacle to the action of enzymes during enzymatic hydrolysis (Robak and Balcerek 2018, Xu et al. 2019). Cellulose accessibility is also influenced by the presence of covalent bonds between lignin and carbohydrates that hinder the selective removal of lignin (Kontturi et al. 2008, Russ et al. 2016, Jablonský et al. 2018a). It is also known that lignin is most likely attached to carbohydrates by the notorious lignin-carbohydrate complex (LCC) linkages (Fu and Lucia 2003). Various authors have assumed that LCC ester/ether linkages between lignin and hemicelluloses that are a part of carbohydrates in lignocellulosic materials are thought to be the major impediments to enzymatic accessibility (Hatfield et al. 1999, Chundawat et al. 2010, Chundawat et al. 2011, Thian Hong 2013). However, lignin as a substantial part of biomass may be a source of aromatic compounds and has the greatest potential to become an essential substance in the future, because in some ways it can substitute fossil fuels as a source of chemicals with added value (Jablonský et al. 2018b). On the other hand, woody biomass generally has a lower content of pentoses than agricultural biomass waste, which is favourable for conversion to second generation bioethanol. Pentose decomposition to furfurals (in particular 5-(hydroxymethyl) furfural and furfural) during thermo-hydro-mechanical pretreatments leads to low yield of monosaccharides and fermentation of pentoses is relatively 
difficult as well (Zhu and Pan 2010). Wood of deciduous trees, including poplar, show a relatively higher lignin content which is more compact than in the typical herbaceous residues. It enhances their high recalcitrance to release monosaccharides during enzymatic hydrolysis (Pažitný et al. 2019a). Nevertheless, poplar wood can provide much higher biofuel amount calculated from certain biomass weight compared to agricultural biomass plants and it is comparable to some grass species (Feng et al. 2017).

Since the structure of poplar wood includes low accessible holocellulose with relatively high cellulose content, correspondingly, harsher pretreatment conditions are required for poplar wood, leading to an increased consumption of thermal energy and to a higher formation of toxic enzymatic hydrolysis and fermentation inhibitors. The amounts of these soluble inhibitors and their distribution depend on the type and severity of pretreatment, concentration of lignocellulosic solids during pretreatment and hydrolysis, and biomass type. (Kim et al. 2011). The toxic enzymatic hydrolysis and fermentation inhibitors become more pronounced as the biomass concentration in the hydrolysis slurry increases (Palmqvist et al. 1996, Tengborg et al. 2001, Jørgensen et al. 2007, Hodge et al. 2008). Therefore, many promising pretreatment methods have been developed to disintegrate the compact woody structure. Steam explosion pretreatment belong to the group of physicochemical pretreatment methods. Continuous variations of steam explosion pretreatment include steam extrusion pretreatment, however, for effective enhancement of cellulose conversion to monosaccharides the use of chemicals such as alkali is required in such pretreatment (Gigac et al. 2017, Stankovská et al. 2018) or they can be combined with batch pretreatments in order to reach higher holocellulose accessibility level (Pažitný et al. 2019b). Steam explosion is a thermo-mechanico-chemical pretreatment which induces a breakdown of lignocellulosic material by chemical modification from in situ generated acids which principally cause the depolymerization of hemicelluloses and by mechanical action due to high shearing forces applied to the lignocellulosic material during the explosive release. The process enhances the recovery of monosaccharides and makes biopolymers such as cellulose and hemicelluloses more accessible for subsequent processes such as enzymatic hydrolysis, fermentation or densification (Pažitný et al. 2019a). The steam explosion process has been extensively studied to improve the enzymatic hydrolysis process of various cellulosic pulp types including agricultural biomass wastes that are produced to a large extent (Jiang and Guo 2016, Pažitný et al. 2019a).

\section{MATERIAL AND METHODS}

\section{Materials}

The parts of white poplar (Populus alba L.) trees - heartwood and sapwood, and coppice, which grew from the roots of the same trees, were obtained from Bratislava region (Slovak Republic). Cellic CTec3 was used as a ready-to-use stabilized enzyme complex supplied by Novozymes A/S (Bagsværd, Denmark) for degradation of lignocellulosic raw material to fermentable monosaccharides. The enzyme activity was measured to be $1.700 \mathrm{BHU}$ (Biomass Hydrolysis Units)/g product in laboratory.

\section{Methods}

Poplar tree parts such as heartwood, sapwood and coppice (Fig. 1) were purified from silt, stripped of leaves, debarked, shaved and pretreated mechanically by dry milling in Brabender mill (Brabender ${ }^{\circledR}, \mathrm{GmbH} \& \mathrm{Co}$. KG, Germany). A bottom sieve was used to obtain a finer fraction, however, a $0.7 \mathrm{~mm}$ mesh screen was finally used for the laboratory experiment. For quantification of components such as lignin, holocellulose and cellulose, the analytical methods were used - 
T 222 om-98 and Tappi UM 250 for Klason and acid soluble lignin determination, Wise's method for holocellulose determination, and ISO 692 for cellulose determination, respectively. Holocellulose includes a water-insoluble fibrous network which is formed by cellulose hydrolysable to glucose and hemicelluloses hydrolysable to various hexoses and pentoses.

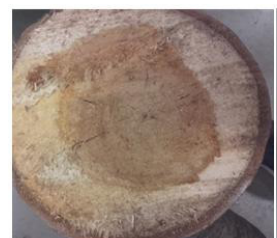

a)

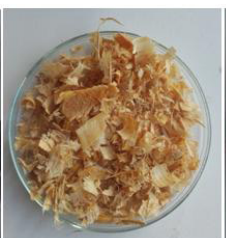

b)

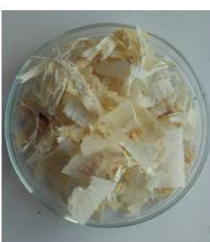

c)

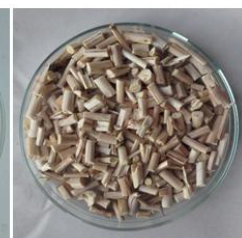

d)

Fig. 1: Samples of poplar (Populus alba L.): (a) cross-section of poplar and mechanically treated parts thereof-(b) heartwood shavings, (c) sapwood shavings, (d) chips of coppice.

The $0.7 \mathrm{~mm}$ poplar particles were impregnated with fresh water so that the final relative humidity of the samples during the steam explosion was $85 \% \mathrm{w} / \mathrm{w}$. The samples were soaked in water at $20^{\circ} \mathrm{C}$ for at least 1 hour prior to steam explosion pretreatment. A quick determination of dry matter in samples was performed on moisture analyser Denver IR35 that uses infrared sample heating. Poplar wood samples $(20 \mathrm{~g}$ o.d. or $50 \mathrm{~g}$ o.d.) were finally pretreated in a $2 \mathrm{~L}$ stainless steel batch reactor for steam explosion pretreatment (Amar Equipments Pvt. Ltd., India). The reactor was used for steam reactions of poplar samples at a temperature of $205^{\circ} \mathrm{C}$. The retention time of each thermo-hydro-mechanical experiment (steam explosion) with poplar wood was $10 \mathrm{~min}$.

Enzymatic hydrolysis of the original and pretreated poplar wood particles with Cellic Ctec3 at an average dose of $0.86 \% \mathrm{w} / \mathrm{w}$ ( $\mathrm{g}$ Cellic Ctec $3 / 100 \mathrm{~g}$ suspension) was carried out in orbital shaker-incubator ES-20/60 (BioSan Ltd., Republic of Latvia) at $50^{\circ} \mathrm{C}, \mathrm{pH}=5.0$ for 72 hours and $12.5 \% \mathrm{w} / \mathrm{w}$ suspension of the poplar samples. The $\mathrm{pH}$ value was adjusted continuously during the hydrolysis process using $0.1 \mathrm{~N}$ sulphuric acid or $0.1 \mathrm{~N}$ sodium hydroxide. The samples of hydrolysed poplar particles were sampled after 24, 48 and 72 hours.

Concentration of monosaccharides and inhibitors was determined using the procedure of National Renewable Energy Laboratory (Sluiter et al. 2008). Monosaccharides (glucose, xylose and arabinose) and inhibitors (formic acid, acetic acid, 5-(hydroxymethyl)furfural and furfural) were determined in hydrolysates by HPLC method with Rezex ROA (organic acid) H+ column. The mobile phase was $0.005 \mathrm{~N}$ sulphuric acid at a flow rate of $0.5 \mathrm{~mL} \cdot \mathrm{min}^{-1}$ and temperature set to $30^{\circ} \mathrm{C}$. Chromatography data processing was performed by the software Clarity version 5.3.0.180 (DataApex Ltd., Czech Republic).

\section{RESULTS AND DISCUSSION}

\section{Poplar wood as a potential lignocellulosic material in $2 \mathrm{G}$ bioethanol production}

Poplar is one of the most known fast-growing trees and is also one of the most utility hardwoods in several countries. It is used for the production of pallets, crates, upholstered furniture frames, paper (pulpwood) and plywood. Wastes obtained from treatment of this hardwood type and from the wooden products made from poplar wood are potentially suitable raw lignocellulosic materials in $2 \mathrm{G}$ bioethanol production. It has been predicted that the total average yield of hybrid poplar (89 millions of tonnes) in Upper Mississippi River Basin, USA, 
covering 493,000 $\mathrm{km}^{2}$, can provide 26 billion litres of biofuel (Tab. 1) which is comparable to some grass species (switchgrass). However, average yields of corn or soybean were calculated several times lower compared to average yield of hybrid poplar and that is why poplar is a more promising lignocellulosic material for $2 \mathrm{G}$ bioethanol production compared to agricultural resources (Feng et al. 2017). According to the predicted data, it is therefore possible to produce more than 292 litres of biofuel from 1 tonne of hybrid poplar biomass on average.

Tab. 1: Biomass and biofuel yield prediction with average biomass yield for switchgrass, Miscanthus, and bybrid poplar (Feng et al. 2017).

\begin{tabular}{|l|c|c|}
\hline \multicolumn{1}{|c|}{ Biomass species } & $\begin{array}{c}\text { Average yield of biomass } \\
\text { (Millions of tonnes) }\end{array}$ & $\begin{array}{c}\text { Biofuel amount } \\
\text { (Billion of litres) }\end{array}$ \\
\hline Switchgrass & 101 & 30 \\
\hline Miscanthus & 268 & 79 \\
\hline Hybrid poplar & 89 & 26 \\
\hline Corn & 34 & 11 \\
\hline Soybean & 9 & 2 \\
\hline
\end{tabular}

In Slovakia, areas forested with coppiced woods originating from stump and root shoots including a higher quality coppice with standards can be used for fast-growing trees such as poplar and also other fast-growing species. Currently they form $5.3 \%$ of the total area of forest stands. The most common among coppice species (including coppice with standards) are oak and black locust. Of the introduced species, black locust is the most prevalent, followed by Austrian pine (Pinus nigra) and cultivated poplars (Green report 2019, Ministry of Agriculture and Rural Development of the Slovak Republic).

\section{Chemical composition of poplar wood from different parts of tree}

The highest holocellulose content was determined in poplar sapwood $(75.3 \% \mathrm{w} / \mathrm{w}$ o.d.) and the lowest holocellulose content was in case of poplar heartwood (63.6 \% w/w o.d.), however, in this case the lowest total lignin content of $19.4 \%$ w/w o.d. was determined. As expected after holocellulose determination, the highest cellulose content determined according to the ISO 692 was achieved in case of poplar sapwood $(49.9 \% \mathrm{w} / \mathrm{w}$ o.d.). It was found that coppice and sapwood (Fig. 1) had a similar chemical composition but other than heartwood (Tab. 2). Heartwood is the oldest tree part and that is why the cellulose and lignin content was higher compared to sapwood or coppice, while content of hemicelluloses was lower in line with the literature (Prosiński 1984).

With respect to the fibrous network comprising total lignin and holocellulose, chemical composition of coppice and sapwood is rather similar to bagasse or cotton stalks. These lignocellulosic materials routinely utilized for papermaking contain comparable amount of ovendry holocellulose and total lignin (Pažitný et al. 2011). They are also expected to be suitable for $2 \mathrm{G}$ bioethanol production as they contain a high proportion of holocellulose. Additionally, the cellulose contents of analysed samples were significantly higher compared to data published for some grass species such as switchgrass or Miscanthus with cellulose content of 40\% w/w (Pažitný et al. 2013). 
Tab. 2: Chemical composition of poplar heartwood, sapwood and coppice.

\begin{tabular}{|l|c|c|c|}
\hline \multirow{2}{*}{ Part of poplar tree } & Holocellulose & Cellulose & Total lignin \\
\cline { 2 - 4 } & \multicolumn{3}{|c|}{ (\% w/w o.d.) } \\
\hline Heartwood & 63.6 & 42.8 & 19.4 \\
\hline Sapwood & 75.3 & 49.9 & 21.5 \\
\hline Coppice shoots & 74.9 & 44.7 & 21.6 \\
\hline
\end{tabular}

As lignin causes inhibition of $2 \mathrm{G}$ bioethanol production processes, in terms of lignin content the most suitable part of poplar tree is poplar heartwood. Compared to lignin content determined for sapwood and coppice, the differences at the level of approximately $1 \% \mathrm{w} / \mathrm{w}$ o.d. are not very significant. However, it should be emphasized that holocellulose and cellulose content in poplar heartwood is much lower compared to poplar sapwood and coppice and they are therefore more appropriate for use in $2 \mathrm{G}$ bioethanol production.

\section{Enzymatic hydrolysis of the steam explosion pretreated poplar wood}

The concentration of monosaccharides was determined in accordance with the procedure of National Renewable Energy Laboratory (Sluiter et al. 2008). The polymeric carbohydrates were hydrolysed into the soluble monomeric forms. They were then measured by the high performance liquid chromatography (HPLC) method. The results showed that the concentrations of monosaccharides were strongly affected by enzymatic hydrolysis time, however, oligomers were not analysed due to their negligible concentration. In general, the concentration of monosaccharides increased with enzymatic hydrolysis time. It was also found that the steam explosion pretreatment of poplar particles at temperature of $205^{\circ} \mathrm{C}$ caused the sharp increase of concentrations of monosaccharides in hydrolysates compared to non-pretreated poplar particles which is consistent with our previous research in this field (Pažitný et al. 2019a, Pažitný 2019). The maximum concentration of total monosaccharides at $90.0 \mathrm{~g} \cdot \mathrm{L}^{-1}$ (enzymatic hydrolysis time of 72 hours) and the highest glucose concentration at $70.4 \mathrm{~g} \cdot \mathrm{L}^{-1}$ (enzymatic hydrolysis time of 48 hours) were achieved in case of pretreated poplar heartwood (Fig. 2). Steam explosion and subsequent enzymatic hydrolysis of poplar heartwood also provided concentration enhancement of two pentoses - xylose with concentrations of $16.4 \mathrm{~g} \cdot \mathrm{L}^{-1}, 16.5 \mathrm{~g} \cdot \mathrm{L}^{-1}, 18.5 \mathrm{~g} \cdot \mathrm{L}^{-1}$, and arabinose with concentrations of $3.3 \mathrm{~g} \cdot \mathrm{L}^{-1}, 2.9 \mathrm{~g} \cdot \mathrm{L}^{-1}$, and $2.6 \mathrm{~g} \cdot \mathrm{L}^{-1}$ for sampling time 24 , 48, and 72 hours, respectively.

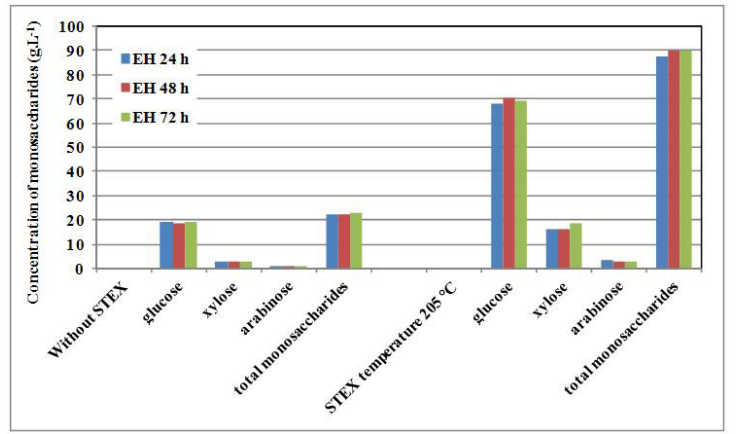

Fig. 2: Effect of steam explosion (STEX) at temperature of $205^{\circ} \mathrm{C}$ on concentration of monosaccharides (glucose, xylose, and total monosaccharides) in hydrolysates obtained during enzymatic hydrolysis (EH) of mechanically treated poplar heartwood. 
Steam explosion pretreatment and subsequent enzymatic hydrolysis of poplar sapwood also gave high glucose and xylose concentrations. The maximum total concentration of monosaccharides (84.9 $\mathrm{g} \cdot \mathrm{L}^{-1}$ ) was achieved after 48 hours of enzymatic hydrolysis. Xylose concentration reached the maximum value $\left(18.1 \mathrm{~g} \cdot \mathrm{L}^{-1}\right)$ after 72 hours of enzymatic hydrolysis (Fig. 3).

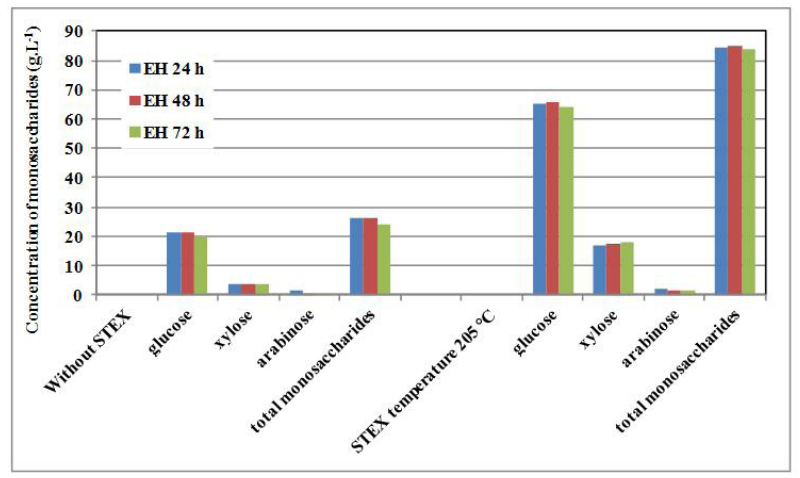

Fig. 3: Effect of steam explosion (STEX) at temperature of $205^{\circ} \mathrm{C}$ on concentration of monosaccharides (glucose, xylose, and total monosaccharides) in hydrolysates obtained during enzymatic hydrolysis (EH) of mechanically treated poplar sapwood.

In experiments with poplar heartwood or poplar sapwood it can be observed that the arabinose concentration decreased with enzymatic hydrolysis time. In contrast, the xylose concentration mildly increased in both enzymatic hydrolysis experiments. The different total concentrations of pentoses in initial hydrolysates of non-pretreated samples might be caused by various ratio of hemicelluloses in poplar heartwood $(20.8 \% \mathrm{w} / \mathrm{w}$ o.d.) and sapwood $(25.4 \%$ w/w o.d.). Eventually, higher lignin content in poplar sapwood compared to poplar heartwood can eventually cause more effective barrier blocking the interaction between enzymes and carbohydrates (Xu et al. 2019).

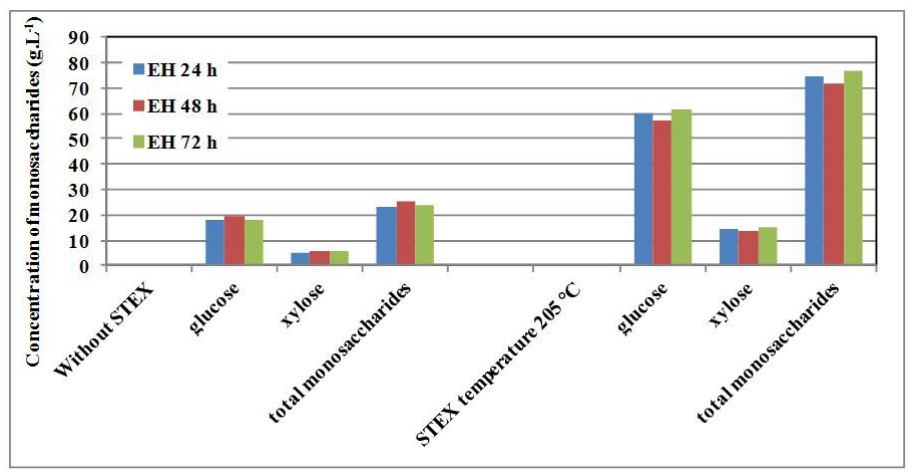

Fig. 4: Effect of steam explosion (STEX) at temperature of $205^{\circ} \mathrm{C}$ on concentration of monosaccharides (glucose, xylose, and total monosaccharides) in hydrolysates obtained during enzymatic hydrolysis (EH) of mechanically treated poplar coppice. 
Glucose and xylose concentrations significantly increased by applying the steam explosion at temperature of $205^{\circ} \mathrm{C}$ to the mechanically treated poplar coppice too. The maximum total concentration of monosaccharides $\left(76.7 \mathrm{~g} \cdot \mathrm{L}^{-1}\right)$ was achieved after 72 hours of enzymatic hydrolysis (Fig. 4). At this hydrolysis time, glucose and xylose concentration reached maximum (61.3 g.L $\mathrm{L}^{-1}$ and $15.4 \mathrm{~g} \cdot \mathrm{L}^{-1}$, respectively). Arabinose was not identified.

Inhibition compounds were also identified and quantified by the HPLC method. The maximum concentration of inhibitors $\left(9.3 \mathrm{~g} \cdot \mathrm{L}^{-1}\right)$ was determined for hydrolysed poplar coppice with culmination after 24 hours of enzymatic hydrolysis. The main inhibitor for each hydrolysed poplar sample was acetic acid acting as a slight hydrolysis inhibitor (Yang et al. 2011). Its concentration ranged from $0.4 \mathrm{~g} \cdot \mathrm{L}^{-1}$ (heartwood) to $1.7 \mathrm{~g} \cdot \mathrm{L}^{-1}$ (sapwood) for the non-pretreated substrates and from $4.9 \mathrm{~g} \cdot \mathrm{L}^{-1}$ (sapwood) to $6.0 \mathrm{~g} \cdot \mathrm{L}^{-1}$ (coppice) for the steam-exploded substrates. Other inhibitors such as formic acid were exclusively observed in the steam exploded substrates, 5-(hydroxymethyl)furfural and furfural were also identified, however, 5-(hydroxymethyl) furfural and furfural were observed only in pretreated and hydrolysed poplar coppice shoots. The maximum concentration of formic acid was determined for hydrolysate of steam explosion pretreated coppice shoots $\left(1.5 \mathrm{~g} \cdot \mathrm{L}^{-1}\right)$. This hydrolysed substrate contained 5-(hydroxymethyl) furfural and furfural with maximum concentrations of $0.6 \mathrm{~g} \cdot \mathrm{L}^{-1}$ and $1.6 \mathrm{~g} \cdot \mathrm{L}^{-1}$, respectively, culminating after 24 hours of enzymatic hydrolysis.

In general, among all poplar tree parts, poplar heartwood provided the maximum concentration which corresponds to the highest accessibility of cellulose for enzyme reagents. Concentrations of monosaccharides in enzymatic hydrolysates of individual poplar tree parts subjected to mechanical treatment and steam explosion pretreatment at high temperature were affected by several factors. Recalcitrance factor that impedes the efficient enzymatic hydrolysis of cellulose is related to the cell wall heterogeneity and the polymer interaction forming a tightly packed structure (Jiang et al. 2017). Such packing density also related to hemicelluloses diffused into the inter-fibrillar space through fibre pores, which physically limits enzyme accessibility to the cellulose molecules (Meng and Ragauskas 2014). The high basic density of the lignocellulosic material in the hydrolysis reaction mixture also contributes to slow down the diffusion of the enzyme within the cellulosic structure, even if the concentrations of additional reagents including enzyme reagents are high. The mechanical treatment of such materials is difficult and energy intensive as well. Soft deciduous species have the lowest basic density, followed by softwoods and then hardwood deciduous species (Petráš et al. 2019). Since poplar wood has a lower basic density at the level of $370 \mathrm{~kg} \cdot \mathrm{m}^{-3}$, which is comparable to some softwoods tree species or even lower, high concentrations of monosaccharides in hydrolysates by using of steam explosion pretreatment are expected and for this reason it is very appropriate to use poplar tree parts in enzymatic hydrolysis and $2 \mathrm{G}$ bioethanol production. For comparison, Miscanthus in compressed form, which is also the lignocellulosic substrate suitable in $2 \mathrm{G}$ bioethanol production, can reach the bulk density of $256 \mathrm{~kg} \cdot \mathrm{m}^{-3}$ (Turner et al. 2018). Eventually, constructional and thermal insulating boards made from some recycled lignocellulosic materials utilizable for $2 \mathrm{G}$ bioethanol production can have density up to $200 \mathrm{~kg} \cdot \mathrm{m}^{-3}$ (Russ et al. 2013).

\section{CONCLUSIONS}

This study demonstrated the potential suitability of the selected parts of poplar tree such as heartwood, sapwood and coppice for enzymatic hydrolysis and $2 \mathrm{G}$ bioethanol production processes. Concentration values were determined for individual monosaccharides in hydrolysates obtained during enzymatic hydrolysis of mechanically treated particles made from poplar. The effect of steam explosion (STEX) at temperature of $205^{\circ} \mathrm{C}$ on concentrations of monomers such as 
glucose, xylose and arabinose was monitored for the individual lignocellulosic samples to evaluate holocellulose accessibility enhancement.

Among all poplar tree parts, heartwood gave the maximum monosaccharides concentration of $90.0 \mathrm{~g} \cdot \mathrm{L}^{-1}$, which corresponds to the highest cellulose and holocellulose accessibility for enzymes. This may be due to the lowest lignin content determined at $19.4 \% \mathrm{w} / \mathrm{w}$ o.d. and the lowest content of hemicelluloses $(20.8 \% \mathrm{w} / \mathrm{w}$ o.d.) that can cause more effective barrier blocking the interaction between enzymes and carbohydrates in the younger poplar tree parts. Glucose concentration culminated at $70.4 \mathrm{~g} \cdot \mathrm{L}^{-1}$ after 48 hours of enzymatic hydrolysis of steam exploded heartwood. Xylose and arabinose were also found in both non-pretreated and steam exploded heartwood and sapwood, however, arabinose was not identified in any of hydrolysates obtained from coppice shoots. The maximum concentration of inhibitors at the level at $9.3 \mathrm{~g} \cdot \mathrm{L}^{-1}$ was determined for steam exploded and subsequently hydrolysed poplar coppice shoots. The concentration of these products culminated after 24 hours of enzymatic hydrolysis. The main inhibitor for each hydrolysed poplar sample was acetic acid which is a slight inhibitor. The maximum concentration of formic acid was determined for hydrolysate of steam exploded coppice $\left(1.5 \mathrm{~g} \cdot \mathrm{L}^{-1}\right)$. This lignocellulosic substrate also contained 5-(hydroxymethyl)furfural $\left(0.6 \mathrm{~g} \cdot \mathrm{L}^{-1}\right)$ and furfural $\left(1.6 \mathrm{~g} \cdot \mathrm{L}^{-1}\right)$.

The obtained results showed that poplar being a fast-growing tree and all selected wooden parts are good lignocellulosic substrate and comparable alternative to some grass species such as switchgrass and Miscanthus for $2 \mathrm{G}$ bioethanol production processes.

\section{ACKNOWLEDGMENTS}

This publication is the result of the project implementation: Centrum excelentnosti lesníckodrevárskeho komplexu LignoSilva (Centre of Excellence of Forest-based Industry, ITMS: 313011S735) supported by the Research \& Development Operational Programme funded by the ERDF.

\section{REFERENCES}

1. Böhlenius, H., Nilsson, U., Salk, C., 2020: Liming increases early growth of poplars on forest sites with low soil pH. Biomass and Bioenergy 138: 105572.

2. Christersson, L., 2008: Poplar plantations for paper and energy in the south of Sweden. Biomass and Bioenergy 32(11): 997-1000.

3. Chundawat, S.P.S., Beckham, G.T., Himmel, M.E., Dale, B.E., 2011: Deconstruction of lignocellulosic biomass to fuels and chemicals. Annual Review of Chemical and Biomolecular Engineering 2: 121-145.

4. Chundawat, S.P.S., Vismeh, R., Sharma, L.N., Humpula, J.F., Sousa, L.D.C., Chambliss, C.K., Jones, A.D., Balan, V., Dale, B.E., 2010: Multifaceted characterization of cell wall decomposition products formed during ammonia fiber expansion (AFEX) and dilute acid based pretreatments. Bioresource Technology 101(21): 8429-8438.

5. DeBell, D.S., Harrington, C.A., 1997: Productivity of Populus in monoclonal and polyclonal blocks at three spacings. Canadian Journal of Forest Research 27(7): 978-985. 
6. Dimitriou, I., Mola-Yudego, B., 2017: Poplar and willow plantations on agricultural land in Sweden: Area, yield, groundwater quality and soil organic carbon. Forest Ecology and Management 383: 99-107.

7. Feng, Q. Chaubey, I., Engel, B., Cibin, R., Sudheer, K.P., Volenec, J., 2017: Marginal land suitability for switchgrass, Miscanthus and hybrid poplar in the Upper Mississippi River Basin (UMRB). Environmental Modelling \& Software 93: 356-365.

8. Fu, S., Lucia, L.A., 2003: Investigation of the chemical basis for inefficient lignin removal in softwood kraft pulp during oxygen delignification. Industrial \& Engineering Chemistry Research 42(19): 4269-4276.

9. Gigac, J., Fišerová, M., Stankovská, M., Pažitný, A., 2017: Enzymatic hydrolysis of extruded wheat straw with addition of sodium hydroxide and calcium hydroxide. Wood Research 62(6): 919-930.

10. Hatfield, R.D., Ralph, J., Grabber, J.H., 1999: Cell wall cross-linking by ferulates and diferulates in grasses. Journal of the Science of Food and Agriculture 79(3): 403-407.

11. Hodge, D.B., Karim, M.N., Schell, D.J., McMillan, J.D., 2008: Soluble and insoluble solids contributions to high-solids enzymatic hydrolysis of lignocellulose. Bioresource Technology 99(18): 8940-8948.

12. Jablonský, M., Majová, V., Škulcová, A., Ház, A., 2018a: Delignification of pulp using deep eutectic solvents. Journal of Hygienic Engineering and Design 22: 76-81.

13. Jablonský, M., Škulcová, A., Malvis, A., Šima, J., 2018b: Extraction of value-added components from food industry based and agro-forest biowastes by deep eutectic solvents. Journal of Biotechnology 282: 46-66.

14. Jiang, S.T., Guo, N., 2016: The steam explosion pretreatment and enzymatic hydrolysis of wheat bran. Energy Sources, Part A: Recovery, Utilization, and Environmental Effects 38(2): 295-299.

15. Jiang, J., Wang, J., Zhang, X., Wolcott, M., 2017: Assessing multi-scale deconstruction of wood cell wall subjected to mechanical milling for enhancing enzymatic hydrolysis. Industrial Crops \& Products 109: 498-508.

16. Jong, J.D., Akselsson, C., Egnell, G., Löfgren, S., Olsson, B.A., 2017: Realizing the energy potential of forest biomass in Sweden - How much is environmentally sustainable? Forest Ecology and Management 383: 3-16.

17. Jørgensen, H., Vibe-Pedersen, J., Larsen, J., Felby, C., 2007: Liquefaction of lignocellulose at high-solids concentrations. Biotechnology and Bioengineering 96(5): 862-870.

18. Kačík, F., Ďurkovič, J., Kačíková, D., 2012: Chemical profiles of wood components of poplar clones for their energy utilization. Energies 5: 5243-5256.

19. Kim, Y., Ximenes, E., Mosier, N.S., Ladisch, M.R., 2011: Soluble inhibitors/deactivators of cellulase enzymes from lignocellulosic biomass. Enzyme and Microbial Technology 48(4-5): 408-415.

20. Kontturi, E., Mitikka-Eklund, M., Vuorinen, T., 2008: Strength enhancement of a fiber network by carboxymethyl cellulose during oxygen delignification of kraft pulp. BioResources 3(1): 34-45.

21. Krutul, D., Antczak, A., Radomski, A., Drożdżek, M., Kłosińska, T., Zawadzki, J., 2019: The chemical composition of poplar wood in relation to the species and age of trees. Annals of Warsaw University of Life Sciences - SGGW. Forestry and Wood Technology 105: 125-132.

22. Mao, R., Zeng, D.-H., Hu, Y.-L., Li, L.-J., Yang, D., 2010: Soil organic carbon and nitrogen stocks in an age-sequence of poplar stands planted on marginal agricultural land in Northeast China. Plant Soil 332(1-2): 277-287. 
23. Meng, X., Ragauskas, A.J., 2014: Recent advances in understanding the role of cellulose accessibility in enzymatic hydrolysis of lignocellulosic substrates. Current Opinion in Biotechnology 27: 150-158.

24. Palmqvist, E., Hahn-Hägerdal, B., Galbe, M., Zacchi, G., 1996: The effect of water-soluble inhibitors from steam-pretreated willow on enzymatic hydrolysis and ethanol fermentation. Enzyme and Microbial Technology 19(6): 470-476.

25. Pažitný, A., 2019: Steam explosion of wood particles from fibreboard and particle board with indirect control by enzymatic hydrolysis. Acta Chimica Slovaca 12(2): 185-191.

26. Pažitný, A., Boháček, Š., Russ, A., 2011: Application of distillery refuse in papermaking: Novel methods of treated distillery refuse spectral analysis. Wood Research 56(4): 533-544.

27. Pažitný, A., Russ, A., Boháček, S., Bottová, V., Černá, K., 2013: Utilization of energetic grass fibre for modification of recovered fibre properties. Wood Research 58(2): 181-190.

28. Pažitný, A., Russ, A., Boháček, Š., Stankovská, M., Ihnát, V., Šutý, Š., 2019a: Various lignocellulosic raw materials pretreatment processes utilizable for increasing holocellulose accessibility for hydrolytic enzymes. Part II. Effect of steam explosion temperature on beech enzymatic hydrolysis. Wood Research 64(3): 437-448.

29. Pažitný, A., Russ, A., Boháček, Š., Stankovská, M., Šutý, Š., 2019b: Various lignocellulosic raw materials pretreatment processes utilizable for increasing holocellulose accessibility for hydrolytic enzymes. Part I. Evaluation of wheat straw pretreatment processes. Wood Research 64(1): 13-24.

30. Petráš, R., Mecko, J., Krupová, D., Slamka, M., Pažitný, A., 2019: Aboveground biomass basic density of softwoods tree species. Wood Research 64(2): 205-212.

31. Prčík, M., Kotrla, M., 2016: Different planting material for establishment of the Miscanthus energy grass plantation. Journal of Central European Agriculture 17(3): 778-792.

32. Prosiński, S., 1984: Wood chemistry. (Chemia drewna). Państwowe Wydawnictwo Rolnicze i Leśne (PWRiL). Warsaw, 475 pp. (in Polish).

33. Robak, K., Balcerek, M., 2018: Review of second generation bioethanol production from residual biomass. Food Technology \& Biotechnology 56(2): 174-187.

34. Russ, A., Fišerová, M., Letko, M., Opálená, E., 2016: Effect of steam explosion temperature on wheat straw enzymatic hydrolysis. Wood Research 61(1): 65-74.

35. Russ, A., Schwartz, J., Boháček, Š., Lübke, H., Ihnát, V., Pažitný, A., 2013: Reuse of old corrugated cardboard in constructional and thermal insulating boards. Wood Research 58(3): 505-510.

36. Sluiter, A., Hames, B., Ruiz, R, Scarlata, C., Sluiter, J., Templeton D., Crocker, D., 2008: Technical Report NREL/TP-510-42618. National Renewable Energy Laboratory (NREL), Golden, CO, USA.

37. Stankovská, M., Fišerová, M., Gigac, J., Pažitný, A., 2018: Effect of alkaline extrusion pretreatment of wheat straw on filtrate composition and enzymatic hydrolysis. Cellulose Chemistry and Technology 52(9-10): 815-822.

38. Stolarski, M.J., Krzyżaniak, M., Szczukowski, S., Tworkowski, J., Bieniek, A., 2013: Dendromass Derived from Agricultural Land as Energy Feedstock. Polish Journal of Environmental Studies 22(2): 511-520.

39. Tengborg, C., Galbe, M., Zacchi, G., 2001: Reduced inhibition of enzymatic hydrolysis of steam-pretreated softwood. Enzyme and Microbial Technology 28(9-10): 835-844.

40. Thian Hong, N., 2013: Twin screw extrusion pre-treatment of wheat straw for biofuel and lignin biorefinery applications. Doctoral dissertation, Wolfson Centre for Materials Processing, Brunel University London. 
41. Tullus, A., Rytter, L., Tullus, T., Weih, M., Tullus, H., 2012: Short-rotation forestry with hybrid aspen (Populus tremula L. $\times$ P. tremuloides Michx.) in Northern Europe. Scandinavian Journal of Forest Research 27(1): 10-29.

42. Tullus, A., Tullus, H., Vares, A., Kanal, A., 2007: Early growth of hybrid aspen (Populus $\times$ wettsteinii Hämet-Ahti) plantations on former agricultural lands in Estonia. Forest Ecology and Management 245(1-3): 118-129.

43. Turner, A.P., Sama, M.P., Bryson, L.S., Montross, M.D., 2018: Effect of stem crushing on the uniaxial bulk compression behaviour of switchgrass and Miscanthus. Biosystems Engineering 175: 52-62.

44. Webb, C.J., Sykes, W.R., Garnock-Jones, P.J., 1988: Naturalised pteridophytes, gymnosperms, dicotyledons. In: Flora of New Zealand. Christchurch: Botany Division. D.S.I.R. Vol. 4, 1365 pp.

45. Xu, C., Zhang, J., Zhang, Y., Guo, Y., Xu, H., Liang, C., Wang, Z., Xu, J., 2019: Lignin prepared from different alkaline pretreated sugarcane bagasse and its effect on enzymatic hydrolysis. International Journal of Biological Macromolecules 141: 484-492.

46. Yang, B., Dai, Z., Ding, S.Y., Wyman, C.E., 2011: Enzymatic hydrolysis of cellulosic biomass. Biofuels 2(4): 421-450.

47. Zhu, J.Y., Pan, X.J., 2010: Woody biomass pretreatment for cellulosic ethanol production: technology and energy consumption evaluation. Bioresource Technology 101(13): 4992-5002.

*Andrej Pažitný, Albert Russ, Štefan Boháček, Monika Stankovská, Vladimír Ihnát Pulp and Paper Research Institute

Dúbravská Cesta i4

84I o4 Bratislava

Slovak Republic

*Corresponding author: pazitny@vupc.sk

Štefan Šutý $_{\text {Slovak University of Technology }}$
Faculty of Chemical and Food Technology
Institute of Natural and Synthetic Polymers
Department of Wood, Pulp and Paper
Radlinského 9
8i 237 Bratislava
Slovak Republic

